\title{
FAKTOR-FAKTOR KONTIJENSI YANG MEMENGARUHI PENGIMPLEMENTASIAN PRAKTIK AKUNTANSI MANAJEMEN PADA USAHA KECIL MENENGAH (UMKM) DI KOTA MATARAM
}

\author{
Herlina Pusparini' \\ Nurabiah2) \\ Yusli Mariadi ${ }^{3}$ ) \\ 1,2,3) Akuntansi FEB Unram \\ 1) h.pusparini@unram.a.c.id \\ 2) nurabiah@unram.ac.id \\ 3)yuslimariadi@unram.ac.id
}

\begin{abstract}
The development of the MSMEs sector (UMKM) shows that there is great potential if this can be managed and developed properly, which will certainly be able to create strong micro, small and medium enterprises. But the inability of UMKM to utilize management accounting tools or practices and the use of management accounting practices (PAM) by Indonesian UMKM are still dominated by traditional PAM and the use of contemporary PAM is still small. Therefore, the aim of this research is to find out how far the implementation of PAM and the contingent factors that influence the implementation of PAM by the UMKM sector in Mataram City, NTB. The respondents in this study were financial staff and owners / managers. The data source used is primary data with questionnaires. The results of this study based on multiple linear regression analysis. The results of this study indicate that the implementation of management accounting practices is quite good even though for small-scale MSMEs, the use of management accounting is not detailed yet. The environmental uncertainty, market competition, qualification levels of internal accounting staff, and company size influence the implementation of management accounting practices (PAM) while the participation of owner or manager do not influence the implementation of PAM
\end{abstract}

Keywords: contingency, management accounting practice, UMKM

\begin{abstract}
Abstrak
Perkembangan sector UMKM yang demikina pesat memperlihatkan bahwa terdapat potensi yang besar jika hal ini dapat dikelola dan dikembangkan dengan baikyang tentunya akan dapat mewujudkan usaha mikro, kecil, dan menengah yang tangguh. Tetapi ketidakmampuan UMKM untuk memanfaatkan alat atau praktik-praktik akuntansi manajemen dan
\end{abstract}




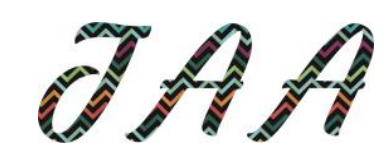

Vol. 5, No. 1, Oktober 2020

penggunaan praktik akuntansi manajemen (PAM) oleh UMKM Indonesia masih didominasi oleh PAM tradisional serta penggunaan PAM kontemporer masih sedikit. Oleh karena itu tujuan penelitian ini adalah ingin mengetahui seberapa jauh pengimplementasian PAM dan factorfaktor kontijensi yang berpengaruh pada pengimplementasian PAM oleh sector UMKM di Kota Mataram NTB. Adapun responden dalam penelitian ini adalah staf keuangan dan pemilik/manajer. Sumber data yang digunakan adalah data primer dengan penyebaran kusioner. Pengujian hipotesis menggunakan analisis regresi linier berganda. Hasil penelitiannya menyatakan bahwa implementasi praktik-praktik akuntansi manajemen sudah cukup bagus walaupun untuk UMKM yang skalanya kecil belum detail penggunaan akuntansi manajemen. Faktor-faktor kontinjensi yang berpengaruh pada pengimplementasian praktik akuntansi manajemen (PAM) yang digunakan oleh UMKM di kota Mataram NTB antara lain ketidakpastian lingkungan, persaingan pasar, tingkat kualifikasi staff akuntansi internal, dan ukuran perusahaan, sedangkan partisipasi pemilik atau manajer belum berpengaruh terhadap pengimplementasian PAM.

\section{Kata kunci: kontijensi, praktek akuntansi manajemen, UMKM}

\section{PENDAHULUAN}

Usaha Mikro, Kecil, dan Menengah (UMKM) memiliki peranan dan kontribusi yang cukup besar bagi perekonomian Indonesia. Hal ini terbukti tahun 2017 ini jumlah pelaku UMKM sebanyak 59.69 juta dari total pelaku usaha nasional dengan rincian yakni usaha mikro 58,9 juta, usaha kecil 716,8 ribu, usaha menengah 65,5 ribu, dan usaha besar 5,03 ribu, selain itu menyumbang terhadap PDB Nasional hingga $62,57 \%$ persen, dan jumlah tenaga kerja yang terserap mencapai 99,9 persen dan jumlah tenaga kerja yang bekerja di sektor ini tercatat 128,06 juta pekerja. (www.depkop.go.id).Perkembangan sektor UMKM yang demikian pesat memperlihatkan bahwa terdapat potensi yang besar jika hal ini dapat dikelola dan dikembangkan dengan baik yang tentunya akan dapat mewujudkan usaha mikro, kecil, dan menengah yang tangguh.

Namum tantangan untuk mengembangkan UMKM tidaklah mudah, butuh political will lebih besar dari pemerintah beserta stakeholder terkait. Banyak masalah yang seringkali mengadang sector ini. Pernyataan Menteri Koordinator Bidang Perekenomian (kontan.co.id.2018) ada tiga permasalahan besar yaitu, pembiayaan, kapasitas sumber daya manusia, kualitas produk dan pemasaran.Salah satu contoh dari segi pembiayaan, secara spesifikhambatan yang bersifat keuangan berupa akses ke sumber modal formal yang terbatas. Sektor ini sulit untuk memperoleh pinjaman modal dari bank atau institusi keuangan lain yang formal. Hal tersebut disebabkan oleh terbatasnya jaminan untuk pinjaman, bentuk usaha yang masih informal, proses birokrasi yang berbelit atau pemilik/manajer UKM 
kurang memiliki informasi yang lengkap mengenai caramemperoleh pinjaman.

Namun, alasan yang paling disorot dari hasil penelitian terdahulu yang menjadi penyebab gagalnya suatu UMKM yakni ketidakmampuan UMKM untuk memanfaatkan alat atau praktik-praktik akuntansi manajemen (Nandan, 2010; Ahmad, 2012).Selain itu penggunaan praktik akuntansi manajemen (PAM) oleh UMKM di Indonesiamasih didominasi oleh PAM tradisional serta penggunaan PAM kontemporer masih sedikit dan terbataspada PAM yang berdampak pada kinerja pelayanan terhadap pelanggan (Prihastini \& Sholihin, 2017).Pada UMKM, PAM berperan sebagai sistem informasi yang mengolahinformasi secara efisien. Selain itu, informasi keuangan dan nonkeuangan yang dihasilkan oleh PAM dapat meningkatkan daya saing serta membantu dalam menghadapi berbagai perubahan yang dialami perusahaan sehingga dapat meningkatkan kinerja (Reid dan Smith, 2002). Penggunaan PAM dapat membantu UMKM dalam mengelola sumber daya yang dimiliki sehingga dapat meningkatkan nilai yang diberikan kepada kustomer dan pemilik/pengelola (Nandan, 2010).

Penggunaan PAM tidak serta-merta menjamin kesuksesan, tetapi tidak menggunakannya berarti mengurangi keunggulankompetitif suatu perusahaan (Folk et al. 2002). Hal ini diperkuat teori kontingensi yang menyatakan bahwa teori perilaku yang mengklaim bahwa tidak ada satu caraterbaik untuk merancang struktur organisasi. Cara terbaikuntuk mengatur misalnya sebuah perusahaan, adalah, bagaimanapun, bergantung pada situasi internal dan eksternal perusahaan.Ada banyak factor kontingensi yang memengaruhi penerapan PAM untuk UMKM ini. Tetapi factor yang paling banyak digunakan peneliti terdahulu (Marcet al., Askarany et al., King et al., Ilias et al., 2010; Ahmad., Neubauer et al., Odar et al., 2012; Armitage et al., Marn et al., 2016; dan Prihastiwi \& Sholihin., 2017) antara lain ukuran perusahaan, staf akuntansi internal, persaingan pasar, ketidakpastian lingkungan, dan partisipasi pemilik. Selain itu penelitian yang serupa lebih banyak dilakukan di luar negeri. Oleh karena itu, peneliti akan meneliti faktor-faktor kontinjensi yang memengaruhi pengimplementasian PAM tersebut di Indonesia khususnya di kota Mataram, Nusa Tenggara Barat.

Faktor kontinjensi pertama adalah tingkat kualifikasi staf akuntansi internal. Praktik-praktik akuntansi manajemen merupakan salah satu sumber dari informasi keuangan. Hasil penelitian Marc et al. (2010) bahwa pengetahuan staf akuntansi internal tentang akuntansi manajemen kontemporer meningkatkan kemungkinan suatu perusahaan untuk menggunakan sistem pengukuran kinerja terintegrasi. Faktor kontinjensi kedua adalah partisipasi dapat memberikan informasi manajerial yang tepat, guna membantu pencapaian tujuan strategic perusahaan. Hal tersebut didukung oleh temuan Ahmad (2012) yang menyebutkan bahwa partisipasi pemilik atau manajer UKM berpengaruh signifikan dan positif 


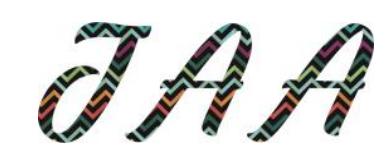

Vol. 5, No. 1, Oktober 2020

terhadap penggunaan anggaran, sistem pengambilan keputusan, akuntansi manajemen strategik, perencanaan dan pengendalian terutama pada pengembangan strategi. Faktor kontinjensi ketiga ialah ukuran perusahaan, Ahmad (2012) menyebutkan bahwa ukuran perusahaan berhubungan positif dan signifikan dengan penggunaan sistem biaya dan sistem penilaian kinerja pada UKM. Faktor kontinjensi keempat adalah ketidakpastian lingkungan, lingkungan eksternal yang bersifat tidak pasti yang dihadapi UKM dapat diantisipasi dan dikendalikan melalui mekanisme internal, yaitu salah satunya dengan menggunakan PAM kontemporer. Hasil ini sesuai dengan penelitian yang dilakukan oleh Marn et al. (2016) yang menyatakan bahwa tingkat ketidakpastian lingkungan memengaruhi secara positif pengadopsian perencanaan strategik pada UKM. Faktor kontinjensi kelima adalah persaingan pasar, Ahmad (2012) menyatakan bahwa persaingan pasar berpengaruh positif dan signifikan terhadap dengan penggunaan sistem biaya dan sistem penilaian kinerja pada UKM.

Berdasarkan latar belakang yang telah diungkapkan maka dapat dirumuskan tujuan yang ingin dicapai dalam penelitian ini antara lain 1) penelitian ini akan menunjukkan seberapa jauh pengimplementasian PAM oleh sektor UMKM di kota Mataram NTB. 2) penelitian ini akan menunjukkan faktor-faktor kontinjensi yang berpengaruh padapengimplementasian PAM yang digunakan oleh UMKM di kota Mataram NTB.

\section{TELAAH LITERATUR DAN PENGEMBANGAN HIPOTESIS}

\section{Teori Kontinjensi}

Teori kontinjensi menyebutkan bahwa tidak ada sistem akuntansi manajemen dan pengendalian yang dapat diaplikasikan secara universal. Teknik akuntansi dan pengendalian yang tepat untuk digunakan bergantung pada keadaan atau faktor-faktor kontinjensi yang mempengaruhi suatu perusahaan. Ada beberapa faktor kontekstual kunci yang dapat memengaruhi ketepatan pemilihan teknik akuntansi yaitu lingkungan eksternal, teknologi (baik tradisional maupun kontemporer), struktur organisasi, ukuran, strategi, dan budaya nasional.(Chenhall, 2003).

Ide Penting dari Teori Kontijensi antara lain : 1) Tidak ada cara yang universal atau yang terbaik untuk mengelola 2) Berbagai faktor eksternal dan internal harus dipertimbangkan dan harus fokus pada tindakan yang paling sesuai dengan situasi tertentu 3) Organisasi yang efektif tidak hanya memiliki 'cocok' tepat dengan lingkungan tetapi juga antara subsistem 4) Kebutuhan organisasi akan lebih memuaskan bila dirancang dan gaya manajemen yang tepat baik untuk tugas yang dilakukan dan sifat dari kelompok kerja. 5) Setiap situasi manajer harus dilihat secara terpisah 6) Manajer perlu dikembangkan dalam 
keterampilan yang paling berguna dalam mengidentifikasi faktor-faktor situasional yang penting

\section{Penelitian Terdahulu}

Tabel 1.Penelitian Terdahulu dan Faktor Kontinjensi yang Digunakan

\begin{tabular}{|c|c|c|c|}
\hline No & $\begin{array}{l}\text { Peneliti } \\
\text { (Tahun) }\end{array}$ & Faktor Kontinjensi & Negara \\
\hline 1 & Ilias et al. (2010) & $\begin{array}{l}\text { Tingkat kualifikasi staf } \\
\text { akuntansi internal }\end{array}$ & Malaysia \\
\hline 2 & $\begin{array}{lll}\text { Marc et al. } \\
(2010)\end{array}$ & $\begin{array}{l}\text { Ukuran perusahaan, } \\
\text { persaingan pasar, tingkat } \\
\text { kualifikasi staf akuntansi } \\
\text { internal, masuk dalam pasar } \\
\text { internasional }\end{array}$ & Slovania \\
\hline 3 & $\begin{array}{l}\text { Askarany et al. } \\
\text { (2010) }\end{array}$ & Ukuran perusahaan & $\begin{array}{l}\text { New } \\
\text { Zealand }\end{array}$ \\
\hline 4 & $\begin{array}{l}\text { King } \\
(2010)\end{array}$ et al. & $\begin{array}{l}\text { Ukuran perusahaan, struktur } \\
\text { organisasi }\end{array}$ & Australia \\
\hline 5 & Ahmad (2012) & $\begin{array}{l}\text { Ukuran perusahaan, } \\
\text { persaingan pasar, partisipasi } \\
\text { pemilik, tingkat kualifikasi } \\
\text { staf akuntansi internal, } \\
\text { teknologi }\end{array}$ & Malaysia \\
\hline 6 & Elhamma (2012) & Ukuran perusahaan & Maroko \\
\hline 7 & $\begin{array}{l}\text { Neubauer et al. } \\
\text { (2012) }\end{array}$ & Ukuran perusahaan & $\begin{array}{l}\text { Austri, } \\
\text { Jerman }\end{array}$ \\
\hline 8 & $\begin{array}{l}\text { Odar et al. } \\
(2012)\end{array}$ & Ukuran perusahaan & Slovania \\
\hline 9 & $\begin{array}{l}\text { Armitage et al. } \\
\text { (2016) }\end{array}$ & $\begin{array}{l}\text { Ketidakpastian lingkungan, } \\
\text { usia perusahaan Kanada } \\
\text { dan Australia }\end{array}$ & Australia \\
\hline 10 & 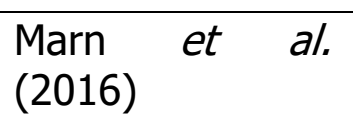 & $\begin{array}{l}\text { Ketidakpastian lingkungan, } \\
\text { motivasi pemilik }\end{array}$ & Malaysia \\
\hline
\end{tabular}

Berdasarkan tabel 1 dapat diketahui bahwa faktor kontinjensi yang paling banyak digunakan yaitu tingkat kualifikasi staf akuntansi internal, ketidakpastian lingkungan, partisipasi pemilik dan persaingan pasar. Hal 


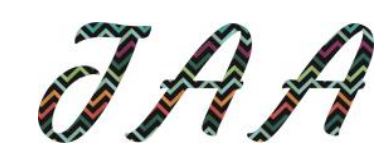

Vol. 5, No. 1, Oktober 2020

lain yang patut diperhatikan tempat penelitian yang dilakukan di negara maju dan hanya sedikit yang dilakukan di negara berkembang.

\section{Pengembangan Hipotesis}

\section{Pengaruh Ketidakpastian lingkungan terhadap Penggunaan Praktik Akuntansi Manajemen}

Lingkungan eksternal yang bersifat tidak pasti yang dihadapi UMKM dapat diantisipasi dan dikendalikan melalui mekanisme internal, yaitu salah satunya dengan menggunakan PAM kontemporer. Hasil ini sesuai dengan penelitian yang dilakukan oleh Marn et al. (2016). Marn et al. menyatakan bahwa tingkat ketidakpastian lingkungan memengaruhi lingkungan, UMKM harus semakin meningkatkan proses perencanaan strategik. Lingkungan industri dan ekonomi akan berdampak pada tingkat ketidakpastian yang dihadapi UMKM karena keterbatasan sumber daya yang dimiliki. Oleh karena itu, UMKM harus menerapkan proses perencanaan yang proaktif dalam menghadapi ketidakpastian tersebut (Marn et al., 2016). Bila tingkat ketidakpastian lingkungan tinggi, penggunaan system akuntansi manajemen yang kontemporer akan berpengaruh positif terhadap kinerja UKM. Akan tetapi, bila tingkat ketidakpastian lingkungan rendah, penggunaan sistem akuntansi manajemen yang kontemporer hanya akan menghambat kinerja UMKM.Semakin tinggi tingkat ketidakpastian pada saat lingkungan eksternal tidak pasti, manajer akan membutuhkan informasi tambahan untuk mengatasi keadaan lingkungan yang kompleks. Oleh karena itu, tingkat ketidakpastian lingkungan eksternal akan mempengaruhi penggunaan PAM.

$\mathrm{H}_{1}$ : Ketidakpastian lingkungan berpengaruh secara positif terhadap penggunaan praktik-praktik akuntansi manajemen.

\section{Pengaruh Persaingan Pasar terhadap Penggunaan Praktik Akuntansi Manajemen}

Beberapa penelitian telah membuktikan bahwa intensitas persaingan pasar dapat mendukung penggunaan sistem akuntansi manajemen dan PAM yang kontemporer. Selain itu, Al-Omiry dan Drury (2007) menemukanbahwa sistem penentuan biaya yang lebih maju berhubungan positif, salah satunya dengan intensitas persaingan. Perusahaan yang menghadapi persaingan pasar yang relatif intens akan cenderung memiliki produk atau jasa yang menghasilkan margin laba rendah karena tekanan untuk menyamai atau bahkan menurunkan harga jual lebih rendah dari harga yang ditetapkan pesaingnya. Pada keadaan tersebut sangat dibutuhkan sistem biaya yang akurat karena sistem biaya yang tidak akurat akan menyebabkan biaya produk/jasa menjadi lebih tinggi atau lebih rendah dari yang seharusnya. 
Marc et al. (2010) menyebutkan bahwa tingkat persaingan yang tinggi memaksa UMKM untuk mendedikasikan seluruh sumber daya yang dimiliki (waktu, uang, dan manusia) untuk menghadapi persaingan pasar tersebut,bukan untuk mengimplementasi teknik-teknik manajemen yang inovatif. Alasan ini didukung oleh temuan Marc et al. (2010) yang menunjukkan bahwa 50\% UKM yang tidak mengimplementasikan BSC karena UKM tidak memahami konsep dan 18\% karena biaya implementasi yang tinggi. Hubungan antara persaingan pasar dengan penggunaan PAM akan diuji dengan menggunakan hipotesis sebagai berikut.

$\mathrm{H}_{2}$ : Persaingan pasar berpengaruh secara positif terhadap penggunaan praktik-praktik akuntansimanajemen.

\section{Pengaruh Tingkat Kualifikasi Staf Akuntansi Internal terhadap Penggunaan Praktik Akuntansi Manajemen}

Marc et al. (2010) menyimpulkan bahwa pengetahuan staf akuntansi internal tentang akuntansi manajemen kontemporer meningkatkan kemungkinan suatu perusahaan untuk menggunakan sistem pengukuran kinerja terintegrasi, seperti misalnya Balanced Scorecardpada UKM di Slovenia. Menurut Sousa et al. (2006) kurangnya keahlian dan pemahaman staf terhadap proses pengukuran kinerja akan menghambat pengadopsian ukuran kinerja baru, terutama yang bersifat nonkeuangan.Beberapa penelitian mengungkapkan bahwa karakteristik dari staf kunci yang dimiliki UKM akanmemengaruhi penggunaan PAM. Keberadaan staf akuntansi internal yang berkualifikasi dapat memengaruhi secara signifikan pengadopsian PAM (Lopez dan Hiebl, 2015). Akan tetapi, keterbatasan sumber daya yang dimiliki akan menyebabkan UKM tidak memiliki staf akuntansi internal atau bila ada, staf akuntansi tersebut tidak memiliki kualifikasi yang sesuai, tidak memiliki pelatihan yang mencukupi, atau tidak termotivasi untuk melakukan inovasi, akan mengurangi kemungkinan pengadopsian PAM (McChlery et al., 2005). Staf akuntansi diharuskan memiliki beberapa tanggung jawab dan peran secara bersamaan, tidak hanya berfokus pada satu area manajerial.Hal tersebut menyebabkan staf tidak memiliki pelatihan yang cukup untuk mengadopsiPAM yang kontemporer (Lopez dan Hiebl, 2015). Hubungan antara tingkat kualifikasi staf akuntansi internal dengan penggunaan PAM akan diuji dengan menggunakan hipotesis sebagai berikut.

$\mathrm{H}_{3}$ : Tingkat kualifikasi staf akuntansi internal berpengaruh secara positif terhadap penggunaanpraktik-praktik akuntansi manajemen.

\section{Pengaruh Partisipasi Pemilik/Manajer terhadap Penggunaan Praktik Akuntansi Manajemen}

Sebagian besar UMKM dimulai dari usaha wiraswasta sehingga pemilik atau manajer memiliki peran utama dalam menentukan kebijakan inovasi UKM, misalnya dalam pengimplementasian sistem informasi 
akuntansi.Penelitian yang dilakukan oleh Ahmad (2012) menyebutkan bahwa partisipasi pemilik atau manajer memiliki hubungan positif dengan penggunaan anggaran, PAM yang berhubungan dengan pengambilan keputusan untuk jangka pendek serta perencanaan dan pengembangan strategi. Hal tersebut karena pada UKM, pemilik atau manajer berperan sebagai pengambil keputusan yang palingutama dan pada umumnya merupakan penentu masa depan perusahaan. Oleh karena itu, pemilik atau manajer yang memiliki rasa tanggung jawab dan komitmen yang tinggi terhadap perusahaan mereka akan mendorong penggunaan PAM yang memberi informasi yang tepat sehingga dapat membantu dalam peningkatan kinerja perusahaan. Jika pemilik atau manajer menganggap akuntansi manajemen hanya sebagai penyedia informasi untuk institusi eksternal (contohnya bank), akuntansi manajemen tidak akan digunakan untuk pengambilan keputusan (Lopez dan Hiebl, 2015). Oleh karena itu, komitmen pemilik atau manajer dalam bentuk partisipasi akan memiliki peran penting dalam pengimplementasian PAM. Pernyataan tersebut akan diuji dengan menggunakan hipotesis berikut.

$\mathrm{H}_{4}$ : Partisipasi pemilik atau manajer berpengaruh secara positif terhadap penggunaan praktik-praktik akuntansi manajemen.

\section{Pengaruh Ukuran Perusahaan terhadap Penggunaan Praktik Akuntansi Manajemen}

Pada umumnya perusahaan yang berukuran lebih besar menggunakan PAM lebih banyak macamnya dan lebih kontemporer dibandingkan dengan perusahaan kecil. Ahmad (2012) yang menyebutkan bahwa ukuran perusahaan berhubungan positif dan signifikan dengan penggunaan sistem biaya dan sistem penilaian kinerja pada UKM. Marc et al. (2010) juga menyebutkan bahwa semakin besar ukuran suatu perusahaan, semakin besar pula kemungkinan UKM tersebut untuk menggunakan sistem penilaian kinerja terintegrasi. Marc et al. (2010) juga menemukan bila suatu UKM telah mencapai suatu ukuran tertentu, peningkatan pada ukurannya tidak akan lagi memengaruhi penggunaan sistem penilaian kinerja. Perusahaan yang berukuran lebih besar juga memiliki proses bisnis yang lebih kompleks sehingga memiliki tantangan yang lebih sulit. Oleh karena itu, perusahaan yang berukuran lebih besar membutuhkan pengendalian dan informasi yang lebih banyak mengenai aktivitasnya sehingga membutuhkan PAM yang komprehensif dan kontemporer (Chenhall, 2003). Hubungan antara ukuran perusahaan dengan PAM akan diuji melalui hipotesis berikut ini.

$\mathrm{H}_{5}$ : Ukuran perusahaan berpengaruh secara positif terhadap penggunaan praktik-praktik akuntansi manajemen. 


\section{METODE PENELITIAN}

\section{Jenis Penelitian}

Jenis penelitian yang digunakan dalam penelitian ini adalah penelitian asosiatif. Penelitian asosiatif bertujuan untuk mengetahui hubungan antara dua variabel atau lebih yang dapat berfungsi untuk menjelaskan, meramalkan dan mengontrol suatu gejala (Sugiyono,2016:36).

\section{Populasi, Sampel dan Teknik Pengambilan Sampel}

Populasi penelitian ini ialah UMKM yang berada di Kota Mataram. Data mengenai populasi diperoleh dari situs web Usaha Mikro Kecil Menengah milik Dinas Perindustrian, Perdagangan dan Koperasi Kota Matraram. Metode proses pengambilan sampel dilakukan secara nonprobabilitas dengan menggunakan teknik pengambilan sampel insidental dan bola salju/snowball. Peneliti menggunakan data dari situs web untuk menentukan letak/wilayah sentra-sentra UKM sebagai titik permulaan penentuan sampel. Dan sampelnya sebanyak 117 UMKM. Penetapan jumlah responden ialah staf accounting, manajer, atau dan pemilik yang paham ataupun yang menggunakan akuntansi manajemen yakni sebanyak 234 responden.

\section{Variabel \& Instumen Penelitian}

Tabel 2.Instrumen Penelitian

\begin{tabular}{|c|c|c|}
\hline Variabel & Indikator & Skala \\
\hline $\begin{array}{l}\text { Penggunaan } \\
\text { praktik } \\
\text { akuntansi } \\
\text { manajemen } \\
\text { (Y) }\end{array}$ & $\begin{array}{l}\text { Job costing (harga pokok pesanan), } \\
\text { biaya variabel, biaya standar, } \\
\text { anggaran penjualan, anggaran } \\
\text { pembelian, anggaran produksi, } \\
\text { anggaran bulanan, anggaran tahunan, } \\
\text { penilaian kinerja berdasarkan laba } \\
\text { operasional, penilaian kinerja } \\
\text { berdasarkan kepuasan pelanggan }\end{array}$ & Likert \\
\hline $\begin{array}{l}\text { Ketidakpastia } \\
n \text { lingkungan } \\
(X 1)\end{array}$ & $\begin{array}{l}\text { 1. Persaingan pembelian bahan baku } \\
\text { 2. Persaingan harga } \\
\text { 3. Jumlah produk yang dipasarkan } \\
\text { 4. tingkat kestabilan lingkungan } \\
\text { eksternal (ekonomi) } \\
\text { 5. klasifikasikan aktivitas-aktivitas } \\
\text { pasar para pesaing } \\
\text { 6. klasifikasikan selera dan preferensi } \\
\text { para pelanggan }\end{array}$ & Likert \\
\hline
\end{tabular}


Vol. 5, No. 1, Oktober 2020

\begin{tabular}{llc}
\hline $\begin{array}{l}\text { Persiangan } \\
\text { Pasar (X2) }\end{array}$ & Keketatan persaingan usaha & Likert \\
\hline Tingkat & 1. Memiliki staf akuntansi internal & Likert \\
Kualifikasi & 2. Pendidikan staf akuntansi internal & \\
Staf & & \\
$\begin{array}{l}\text { Akuntansi } \\
\text { Internal (X3) }\end{array}$ & \\
\hline $\begin{array}{l}\text { Partisipasi } \\
\text { pemilik dan } \\
\text { manajer (X4) }\end{array}$ & Partisipasi pemilik atau manajer & Likert \\
\hline $\begin{array}{l}\text { Ukuran } \\
\text { perusahaan } \\
\text { (X5) }\end{array}$ & Jumlah karyawan & \\
\hline
\end{tabular}

Sumber : Data Skunder (2019)

\section{Profil UMKM}

HASIL PENELITIAN DAN PEMBAHASAN

Responden pada penelitian ini adalah staff akuntansi dan pemilik atau manajer UMKM yang ada di Kota Mataram. Jumlah populasi penelitian ini adalah 117 UMKM dengan 234 responden. Tetapi yang yang mengisi kusioner hanya 85 UMKM sehingga total responden yang mengisi kusioner sebanyak 170 orang. Profil UMKM ini dimaksudkan untuk menjelaskan latar belakang UMKM yang menjadi sampel dalam penelitian ini. 
Tabel 3. Profil UMKM

\begin{tabular}{lcc}
\multicolumn{1}{c}{ Keterangan } & Jumlah & Prosentase \\
\hline Lama perusahaan beroperasi & & \\
1. 1 s.d. 10 tahun & 48 & $56 \%$ \\
2. 10 s.d. 20 tahun & 23 & $27 \%$ \\
3. Di atas 20 tahun & 14 & $16 \%$ \\
Aktivitas utama perusahaan & & \\
1. Jasa & 14 & $16 \%$ \\
2. perdagangan & 64 & $75 \%$ \\
3. Produksi & 6 & $7 \%$ \\
4. lainnya & 1 & $1 \%$ \\
Total penjualan per tahun & & \\
1. Kurang dari 100 juta & & \\
2. 101 juta s.d. 500 juta & & \\
3. 501 juta s.d. 1 Milyar & 21 & $25 \%$ \\
4. Di atas 1 Milyar & 39 & $46 \%$ \\
& 10 & $12 \%$ \\
\end{tabular}

Sumber: data diolah 2019

Dari tabel 3 dapat dilihat bahwa lama UMKM beroperasi cukup berimbang antara 10 sampai di atas 20 tahun. Dari segi aktivitas perusahaan didominasi sector perdagangan. Dan total penjualan cukup didominasi dari 101 s.d. 500 juta pertahun.

Pengujian hipotesis dalam penelitian ini menggunakan analisis regresi linear berganda dengan bantuan alat SPSS. Dimana sebelum menguji hipotesis penelitian terlebih dahulu melakukan uji kualitas data (uji validitas, uji reliabilitas) dan uji asumsi klasik (uji normalitas, uji heteroskesdastisitas, dan uji multikolinieritas) dan penelitian ini memenuhi uji kualitas data dan uji asumsi klasik. Hasil pengujian hipotesis disajikan pada tabel 4. 
Table 4. Hasil Uji Hipotesis (Uji Statistik t)

\begin{tabular}{lccccc}
\hline \multicolumn{1}{c}{ Model } & B & t hitung & t tabel & Sig. & Keterangan \\
\hline X1_KPL & 0,447 & 2,083 & 1,655 & 0,042 & $\mathrm{H}_{1}$ Diterima \\
\hline X2_PP & 0,705 & 4,437 & 1,655 & 0,000 & $\mathrm{H}_{2}$ Diterima \\
\hline X3_TKAI & 0,300 & 2,178 & 1,655 & 0,031 & $\mathrm{H}_{3}$ Diterima \\
\hline X4_PPM & 0,074 & 1,145 & 1,655 & 0,255 & $\mathrm{H}_{4}$ Ditolak \\
\hline X5_UP & 0,315 & 2,152 & 1,655 & 0,034 & $\mathrm{H}_{5}$ Diterima
\end{tabular}

Sumber: data diolah 2019

Berdasarkan tabel 4, dapat kita lihat bahwa variabel yang memiliki nilai $t$ hitung lebih besar dari t tabel yaitu diatas 1,65 maka variabel tersebut berpengaruh positif terhadap penggunaan praktik-praktik akuntansi manajemen antara lain ketidakpastian lingkungan, persaingan pasar, tingkat kualifikasi staf akuntansi internal, dan ukuran perusahaan. Sedangkan partisipasi pemilik/manajer tidak berpengaruh terhadap penggunaan praktik-praktik akuntansi manajemen.

\section{Pembahasan Hasil Pengujian Hipotesis \\ Pengaruh Ketidakpastian Lingkungan Terhadap Penggunaan Praktik-Praktik Akuntansi Manajemen.}

Berdasarkan hasil pengujian hipotesis menunjukkan bahwa ketidakpastian lingkungan berpengaruh postif terhadap penggunaan praktik-praktik akuntansi manajemen. Hal ini dapat dilihat dari nilai $\mathrm{t}$ statistik di atas 2,083 (t tabel 5\%) yakni sebesar 1,655. Ini menandakan bahwa semakin tinggi ketidakpastian lingkungan yang terjadi di UMKM tersebut maka penggunaaan praktik-praktik akuntansi manajemen semakin tinggi juga. Dan sebaliknya semakin rendah ketidakpastian lingkungan maka semakin rendah juga penggunaan PAM. Hal ini juga bisa dilihat bahwa UMKM di Kota Mataram menyadari bahwa begitu penting persaingan dalam hal pembelian bahan baku dan persaingan harga, banyaknya produk yang beredar di Masyarakat dan ketidakstablian ekonomi sehingga mau tidak mau UMKM harus menggunakan praktikpraktik PAM seperti harus menghitung harga pokok pesanan, anggaran pembelian, anggaran produksi, anggaran bulanan, anggaran tahunan, penilaian kinerja berdasarkan laba operasional, penilaian kinerja berdasarkan kepuasan pelanggan.

Selain itu biasanya dalam suasana ketidakpastian Lingkungan UMKM akan mengalami kesulitan dalam membuat perencanaan, pengorganisasian, dan melakukan pengendalian terhadap perusahaan. Sehingga perencanaan, pengorganisasian, dan pengendalian akan menjadi masalah dalam situasi ketidakpastian lingkungan yang tinggi. Untuk 
mengatasi itu dibutuhkan penggunaan PAM seperti informasi para pelanggan, para pesaing, data ekonomi, demografi dan lainnya justru saat ini sering dipandang sebagai informasi yang bersifat strategis. Hal ini mendukung penelitian dari Santi (2010) yang menunjukkan bahwa ketidakpastian lingkungan berpengaruh positif terhadap Sistem Informasi Akuntansi Manajemen. Begitu juga lingkungan eksternal yang bersifat tidak pasti yang dihadapi UKM dapat diantisipasi dan dikendalikan melalui penggunaan PAM. Hasil ini sesuai dengan penelitian yang dilakukan oleh Marn et al. (2016). yang menyatakan bahwa tingkat ketidakpastian lingkungan memengaruhi secara positif pengadopsian perencanaan strategik pada UKM. Semakin tinggi tingkat ketidakpastian lingkungan, UKM harus semakin meningkatkan proses perencanaan strategik.

Hal ini sejalan dengan teori kontijensi yang menyebutkan bahwa teknik akuntansi dan pengendalian yang tepat untuk digunakan bergantung pada keadaan atau faktor-faktor kontinjensi yang mempengaruhi suatu perusahaan. Salah satu factor kontijensi yaitu ketidakpastian lingkungan. Selain itu adanya pernyataan bahwa organisasi yang efektif tidak hanya memiliki 'cocok' tepat dengan lingkungan tetapi juga antara subsistem.

\section{Pengaruh Persaingan Pasar Terhadap Penggunaan Praktik- Praktik Akuntansi Manajemen.}

Berdasarkan hasil pengujian hipotesis menunjukkan bahwa persaingan pasar berpengaruh postif terhadap penggunaan praktik-praktik akuntansi manajemen. Hal ini dapat dilihat dari nilai t statistik di atas 4,437 (t tabel 5\%) yakni sebesar 1,655. Ini menandakan bahwa semakin tinggi persaingan pasar yang terjadi di UMKM tersebut maka penggunaaan praktik-praktik akuntansi manajemen semakin tinggi juga. Dan sebaliknya semakin rendah persaingan pasar maka semakin rendah juga tingkat penggunaan PAM. Hal ini juga bisa dilihat bahwa UMKM di Kota Mataram mengalami persaingan pasar yang ketat setiap harinya, apalagi di sektor perdagangan dimana sektor perdagangan sangat mendominasi sektor usaha di Kota Mataram. Dengan adanya persaingan pasar yang ketat mau tidak mau UMKM harus mempraktikan penggunaan akuntansi manajemen seperti menganalisis perkembangan pasar, mengklasifikasikan aktivitasaktivitas pasar para pesaing, mengklasifikasikan selera dan preferensi para pelanggan, dengan tujuan agar UMKM bisa bertahan dengan adanya persaingan pasar yang ketat.

Hasil penelitian ini mendukung hasil penelitian yang telah dilakukan sebelumnya oleh Khandwalla, (1972); Al-Omiri dan Drury, (2007); Hansen dan Van der Stede, (2004); Ahmad, (2012) yang menyatakan bahwa UKM dalam mengahadapi persaingan UMKM membutuhkan pengimplementasian teknik-teknik manajemen yang inovatif. Dan ini juga sejalan dengan teori kontinjensi menyebutkan bahwa tidak ada sistem 


\section{$D A A$}

Vol. 5, No. 1, Oktober 2020

akuntansi manajemen dan pengendalian yang dapat diaplikasikan secara universal. Teknik akuntansi dan pengendalian yang tepat untuk digunakan bergantung pada keadaan atau faktor-faktor kontinjensi yang mempengaruhi suatu perusahaan (Chenhall, 2003). Selain itu teori kontijensi menyatakan bahwa berbagai faktor eksternal dan internal harus dipertimbangkan dan harus fokus pada tindakan yang paling sesuai dengan situasi tertentu sehingga UMKM bisa bertahan dalam menghadapi persaingan apapun

\section{Pengaruh Tingkat Kualifikasi Staff Akuntansi Internal Terhadap Penggunaan Praktik-Praktik Akuntansi Manajemen.}

Berdasarkan hasil pengujian hipotesis menunjukkan bahwa tingkat kualifikasi staff akuntansi internal berpengaruh postif terhadap penggunaan praktik-praktik akuntansi manajemen. Hal ini dapat dilihat dari nilai t statistik di atas 2,178 (t tabel $5 \%$ ) yakni sebesar 1,655 . Ini menandakan bahwa semakin tinggi tingkat kualifikasi staff akuntansi internal yang ada di UMKM tersebut maka penggunaaan praktik-praktik akuntansi manajemen semakin tinggi juga. Dan sebaliknya semakin rendah tingkat kualifikasi staff akuntansi internal maka semakin rendah juga tingkat penggunaan PAM. Hal ini juga bisa dilihat bahwa UMKM di Kota Mataram sudah cukup banyak yang memiliki staf keuangan walapun dengan tingkat pendidikan SMK, tetapi waktu di SMK staff keuangannya sudah mempelajari dasar-dasar akuntansi baik akuntansi keuangan maupun akuntansi manajemen.

Hal ini sejalan dengan pendapat Collis dan Jarvis (2002) dan Marc et al. (2010) yang menyatakan bahwa staf akuntansi internal yang berkualifikasi dan memiliki tingkat pendidikan dan pelatihan mengenai akuntansi yang tinggi akan dapat membantu pengembangan sistem akuntansi manajemen serta analisis dari informasi akuntansi yang dihasilkan oleh sistem tersebut, dimana informasi anggaran dan praktik akuntansi kontemporer yang digunakan untuk perencanaan dan pengendalian keuangan juga bergantung pada ketersediaan staf akuntansi internal yang ahli dan profesional.

Hasil penelitian ini juga sejalan dengan teori kontinjensi menyebutkan bahwa teknik akuntansi dan pengendalian yang tepat untuk digunakan bergantung pada keadaan atau faktor-faktor kontinjensi yang mempengaruhi suatu perusahaan. Dimana Ada beberapa faktor kontekstual kunci yang dapat memengaruhi ketepatan pemilihan teknik akuntansi yaitu lingkungan eksternal, teknologi (baik tradisional maupun kontemporer), struktur organisasi, ukuran, strategi, dan budaya nasional (Chenhall, 2003). 


\section{Pengaruh Partisipasi Pemilik/Manajer Terhadap Penggunaan Praktik-Praktik Akuntansi Manajemen.}

Berdasarkan hasil pengujian hipotesis menunjukkan bahwa partisipasi pemilik tidak berpengaruh terhadap penggunaan praktik-praktik akuntansi manajemen. Hal ini dapat dilihat dari nilai $t$ statistik di bawah 1,145 (t tabel $5 \%$ ) yakni sebesar 1,655 . Ini menandakan bahwa sebanyak atau sedikit apapun partisipasi pemilik itu tidak mempengaruhi penggunaaan praktik-praktik akuntansi manajemen di UMKM tersebut. Hal ini juga bisa dilihat bahwa peran pemilik UMKM di Kota Mataram tidak terlalu berpartisipasi dalam pengggunaan PAM. Hal ini disebabkan para pemilik tidak terlalu paham dengan hal-hal yang berhubungan dengan akuntansi manajemen. Selain itu pemilik atau manajer perusahaan yang tidak memiliki motivasi oleh memperoleh keuntungan yang tinggi, peningkatan mutu dan ide produk baru, dan pengembangan pribadi cenderung tidak memiliki keinginan atau dorongan yang kuat untuk memajukan usahanya. Hal ini terlihat ada beberapa UMKM yang tahun berdirinya sudah lama tetapi nilai keuntungannya tidak bertambah setiap tahunnya.

Selain itu pihak pemilik atau manajer tidak berkomitmen dalam penggunaan PAM ini dimana penentu gaya manajemen perusahaan dan penggunaan PAM terbaik yang dapat memberikan informasi manajerial yang tepat, guna membantu pencapaian tujuan strategik perusahaan dan bahwa sistem informasi akuntansi manajemen itu bukan hanya dianggap sebagai sekelompok jasa pelayanan dalam bentuk pengolahan transaksitransaksi bisnis dan untuk kepentingan pencatatan akuntansi UMKM tetapi sistem informasi akuntansi manajemen juga digunakan sebagai pensuplai informasi yang dibutuhkan dalam laporan bisnis dan sebagai alat dalam mengambil keputusan yang efektif oleh manajer UMKM tersebut.

Hal ini bertolak belakang dengan teori kontinjensi yang menyebutkan bahwa kebutuhan organisasi akan lebih memuaskan bila dirancang dan gaya manajemen yang tepat baik untuk tugas yang dilakukan dan sifat dari kelompok kerja, setiap situasi manajer harus dilihat secara terpisah dan manajer perlu dikembangkan dalam keterampilan yang paling berguna dalam mengidentifikasi faktor-faktor situasional yang penting

\section{Pengaruh Ukuran Perusahaan Terhadap Penggunaan Praktik- Praktik Akuntansi Manajemen.}

Berdasarkan hasil pengujian hipotesis menunjukkan bahwa tingkat kualifikasi staff akuntansi internal berpengaruh postif terhadap penggunaan praktik-praktik akuntansi manajemen. Hal ini dapat dilihat dari nilai t statistik di atas 2,152 (t tabel 5\%) yakni sebesar 1,655. Ini menandakan bahwa semakin besar ukuran UMKM maka penggunaaan praktik-praktik akuntansi manajemen semakin tinggi juga. Dan sebaliknya 
semakin kecil ukuran UMKM maka semakin rendah juga tingkat penggunaan PAM. Hasil ini sesuai dengan penelitian yang dilakukan oleh Ahmad (2012) yang menyebutkan bahwa ukuran perusahaan berhubungan positif dan signifikan dengan penggunaan sistem biaya dan sistem penilaian kinerja pada UKM. Selain itu didukung Marc et al. (2010) yang menyatakan bahwa semakin besar ukuran suatu perusahaan, semakin besar pula kemungkinan UKM tersebut untuk menggunakan sistem penilaian kinerja terintegrasi dan bila suatu UKM telah mencapai suatu ukuran tertentu, peningkatan pada ukurannya tidak akan lagi memengaruhi penggunaan sistem penilaian kinerja. Hansen dan Van der Stede (2004) juga melaporkan bahwa ukuran perusahaan mendorong penggunaan anggaran yang bertujuan untuk penilaian kinerja dan pengomunikasian tujuan perusahaan.

Hasil penelitian ini sejalan dengan teori kontinjensi menyebutkan bahwa ada beberapa faktor kontekstual kunci yang dapat memengaruhi ketepatan pemilihan teknik akuntansi yaitu lingkungan eksternal, teknologi (baik tradisional maupun kontemporer), struktur organisasi, ukuran perusahaan, strategi, dan budaya nasional (Chenhall, 2003), dan organisasi yang efektif tidak hanya memiliki 'cocok' tepat dengan lingkungan tetapi juga antara subsistem serta kebutuhan organisasi akan lebih memuaskan bila dirancang dan gaya manajemen yang tepat baik untuk tugas yang dilakukan dan sifat dari kelompok kerja.

\section{Kesimpulan}

\section{SIMPULAN}

1. Implementasi praktik-praktik akuntansi manajemen oleh sektor UMKM di kota Mataram NTB sudah cukup bagus walaupun untuk UMKM yang skalanya kecil belum detail penggunaan akuntansi manajemen. UMKM sudah menerapkan beberapa hal yang berkaitan dengan akuntansi manajemen antara lain menghitung job costing (harga pokok pesanan), biaya variabel, biaya standar, anggaran penjualan, anggaran pembelian, anggaran produksi, anggaran bulanan, anggaran tahunan, penilaian kinerja berdasarkan laba operasional, penilaian kinerja berdasarkan kepuasan pelanggan

2. Faktor-faktor kontinjensi yang berpengaruh pada pengimplementasian praktik akuntansi manajemen (PAM) yang digunakan oleh UMKM di kota Mataram NTB antara lain ketidakpastian lingkungan, persaingan pasar, tingkat kualifikasi staff akuntansi internal, dan ukuran perusahaan, sedangkan partisipasi pemilik atau manajer belum berpengaruh terhadap pengimplementasian PAM.

\section{Keterbatasan dan Saran}

1. keterbatasan menggunakan faktor-faktor kontijensi yang lain yang berpengaruh terhadap pengimplementasin akuntansi manajemen, oleh 
karena itu sebaiknya peneliti selanjutnya bisa menambahkan faktorfaktor yang lain seperti struktur organisasi, masuk dalam pasar nasional/internasional, teknologi, usia perusahaan, dan motivasi pemilik.

2. Diharapkan pada penelitian selanjutnya bisa lebih memperluas rentang penelitian seperti penelitian seluruh UMKM di pulau lombok atau di NTB. Dengan banyaknya sampel akan semakin memperkuat hasil dari penelitian tersebut. Dan untuk penelitian selanjutnya akan lebih banyak memuat penelitian terdahulu untuk lebih menguatkan penelitiannya, karena pada penelitian ini menggunakan cukup sedikit penelitian terdahulunya. Sehingga diharapkan pada penelitian selanjutnya dapat lebih banyak penggunaan penelitian terdahulu atas variabel yang digunakan.

3. Metode analisa yang digunakan dimungkinkan ada penambahan sesi wawancara dan observasi perusahaan agar data-data yang diisi tidak terlalu bias karena penggunaan kusioner cukup terbatas untuk mengukur kebenaran data tersebut.

\section{DAFTAR PUSTAKA}

Ahmad, K. 2012. The use of management accounting practices in Malaysian SMEs. PhD Dissertation, University of Exeter, United Kingdom.

Al-Omiri, M., dan C. Drury. 2007. A survey of factors influencing the choice of product costing systems in UK organizations. Management Accounting Research, 18: 399-424.

Armitage, H. M., A. Webb, dan J. Glynn. 2016. The use of management accounting techniques by small and medium-sized enterprises: a field study of Canadian and Australian practices. Accounting Perspectives, 15: 31-69.

Chenhall, R. H. 2003. Management control systems design within its organizational context: findings from contingency-based research and directions for the future. Accounting, Organizations and Society, 28: 127-168.

Folk, J. M., H. G. Ray, dan W. N. Eric. 2002. Introduction to Managerial Accounting. New York: McGrawHill.

Ilias, A., M. Z. A. Razak, dan M. R. Yasoa'. 2010. The preliminary study of management accounting practices (MAPs) in Small Business. Global Business and Management Research: An International Journal, 2: 79-88.

Kontan.co.id. diakses pada tanggal 10 Februari 2019 


\section{JAA}

Vol. 5, No. 1, Oktober 2020

Lopez, O. L., dan M. R. W. Hiebl. 2015. Management accounting in small and medium-sized enterprises: current knowledge and avenues for further research. Journal of Management Accounting Research, 27: 81-119.

Marc, M., D. Peljhan, N. Ponikvar, A. Sobota, dan M. Tekavcic. 2010. Determinants Of Integrated Performance Measurement Systems Usage: An Empirical Study. The Journal of Applied Business Research, 26: 63-76.

Marn, J. T. K., C. W. Hin, dan A. M. Bohari. 2016. Antecedents of strategic planning of small and mediumsized enterprises in Malaysia: the influence of ownership motivations and environmental uncertainty.International Review of Management Marketing, 6: 270-276.

McChlery, S., L. Meechan, dan A. D. Godfrey. 2005. Barriers and catalysts to sound financial management systems in small sized enterprises. CIMA: Research Executive Summaries Serries, 1.

Nandan, R. 2010. Management Accounting Needs Of Smes And The Role Of Professional Accountants: A Renewed Research Agenda. Journal of Management Accounting Research (JAMAR), 8: 65-77.

Prihastini \& Sholihin, 2017.Penggunaan Praktik-Praktik Akuntansi Manajemen

Pada Usaha Kecil Menengah Dan Faktor-FaktorKontinjensinya.SNA XX Jember.

Reid, G. C. dan J. A. Smith. 2002. The bigger picture. Financial Management.

Santi, Paramita. 2010. Pengaruh Ketidakpastian Lingkungan Terhadap Sistem Informasi Akuntansi Manajemen dengan Variabel Moderasi Locus Of Control. Skripsi Universitas Mataram

Sugiyono. 2016. Metode Penelitian Bisnis. Bandung: Indonesia. Alfabeta.

Sousa, S. D., E. M. Aspinwall, P. A. Sampaio, dan A. G. Rodrigues. 2005. Performance measures and quality tools in Portuguese small and medium enterprises: survey results. Total Quality Management, 16: 277- 307.

www.depkop.go.id, diaksespada tanggal 10 Februari 2019. 